\title{
The autumn and spring diet of brown bear Ursus arctos in the Bieszczady Mountains of Poland
}

\author{
Witold FRĄCKOWIAK and Roman GULA
}

\begin{abstract}
Frąckowiak W. and Gula R. 1992. The autumn and spring diet of brown bear Ursus arctos in the Bieszczady Mountains of Poland. Acta theriol. 37: 339 - 344.

The diet of brown bear Ursus arctos Linnaeus, 1758 in the autumn of 1990 and the spring of 1991 was studied by the analysis of faeces contents (46 samples, 23 from autumn and 23 from spring). Based on frequency of occurrence of food items in individual faeces, the autumn diet of bears was more diverse than the spring diet. We calculated for each food item frequency percent (F\%), dry weight percent (W\%) and Importance Value (IV\%). Beech Fagus silvatica nuts were the most important food during both spring and autumn (36.9\% IV in autumn and $78.5 \%$ IV in spring). Carrion, used as a bait by hunters, and foodstuffs from game-feeding stations (maize, oats, beets) also appeared to be a significant part of the bears' diet.
\end{abstract}

Department of Wildlife Research, Institute of Environmental Biology, Jagiellonian University, Ingardena 6, 30-060 Kraków, Poland

Key words: Ursus arctos, diet, Bieszczady Mts, Poland

\section{Introduction}

Due to low human densities, a diverse environment and intensive game management, the Bieszczady area is an exceptionally good habitat for brown bear Ursus arctos Linnaeus, 1758. These three factors, together with the species' legally protection since 1952 have allowed rapid growth of the bear population in Bieszczady Mountains. Compared to an estimated 10 individuals shortly after World War II (Jakubiec and Buchalczyk 1987), the present population consists of about 80 individuals, the largest population in Poland (Jakubiec and Buchalczyk 1987, Gula 1991). So far, research on Polish brown bears has been confined to estimations of population size and the species' distribution (Buchalczyk 1980, Jakubiec and Buchalczyk 1987, Jamrozy 1989, Gula 1991).

The aim of this preliminary study was to analyze the diet of brown bears during spring and autumn. During these periods, hunters put large amounts of maize, beets and carrion in front of blinds in order to attract wolves, wild boars, and red deer. Information about the degree to which bears take advantage of these additional food sources could help in efforts to preserve the species and to resolve conflicts between the growing numbers of bears and humans. 


\section{Study area, materials and methods}

The Bieszczady Mountains, situated in southeastern Poland, are a part of the Eastern Beskid range of the Carpathians. They are characterized by a mountain climate: winter starts at the beginning of December and lasts till the end of March; early spring begins in mid-March (Michna and Paczos 1972). The winter of $1991 / 92$ was an average one. The area was covered with snow from the beginning of December to the beginning of March; only on the northern slopes did snow cover last through the end of March. Beech woods Fagetum Carpaticum are the dominant plant association in the Bieszczady Mts. Upper timberline occurs at elevations of $1100-1150 \mathrm{~m}$. Alpine meadows cover areas above this elevation.

The study was carried out within two forest management districts, Stuposiany and Lutowiska, whose total forest area equals 29,800 ha. Brown bears' faeces were collected during 1 Oct - 20 Nov 1990 and 1 - 25 March 1991. They were collected along forest roads and paths and also during tracking. Only fresh faeces, i.e. not older than ca. 7 days, were sampled. The material (46 faecal samples) was stored in plastic bags in a freezer.

Samples taken from the freezer were dried at $60^{\circ} \mathrm{C}$ until their weight became stable, and then they were soaked in cold water with detergents. After 24 hours samples were washed with cold running water on a $1.5 \mathrm{~mm}$ mesh sieve. Subsequently, the content of each sieve was divided into the different kinds of food. Qualitative analysis was performed by means of macro- and microscopic examination; small plant pieces that could not be analyzed qualitatively were classed as an unidentified fraction. The separated components were dried again at $60^{\circ} \mathrm{C}$ for 24 hours and then their dry weight was determined. The difference between the total dry weight of all the components before and after washing was due to the loss of small $(<1.5 \mathrm{~mm})$ unidentifiable food particles. The digested material was not analyzed quantitatively.

Frequency percent (F\%) was calculated for each food item in a given season, and also percent dry weight of each food item (W\%) in individual samples. Subsequently, a mean W\% was calculated for each season. To assess the importance of each food item in the diet we calculated Importance Values (IV) (Sumner and Craighead 1973):

$$
\mathrm{IV}_{\mathrm{i}}=\frac{\mathrm{F}_{\mathrm{i}} \% \times \mathrm{W}_{\mathrm{i}} \%}{100}
$$

and expressed it in percentages (IV\%) (Aoi 1985) of sum total of IVs.

\section{Results}

A total of 46 faecal samples, 23 from autumn and 23 from spring, was analyzed. We collected 7 autumn samples in October and 16 in November. All spring samples were collected in March. Digested parts, i.e. those washed away through a sieve, constituted $40 \%$ of the dry weight in the autumn samples but only $29 \%$ of the spring samples.

Autumn faeces contained more various food items compared to spring (Kolmogorov-Smirnov test, $p<0.05$ ). In autumn in 7 faeces only one class of food item occurred, 9 faeces contained from 2 to 4 classes, and 7 faeces contained more then 4 classes of food items (i.e. 5 or 6). Among spring samples in 11 faeces only one class of food item was found, in other 11 faeces -2 or 3 classes, and only one scat was composed of the remains of 4 various food items. 
Autumn samples contained 17 different food items, out of which 4 were in trace amounts, i.e. they constituted less than $0.5 \%$ of the dry weight of the faeces (Table 1). Spring samples contained 12 food items including 4 in trace amounts.

Beech nuts, pears, oats and maize comprised the largest dry weight fraction in autumn samples (all 10\% dry weight). In spring, only beechnuts and maize amounted to over $10 \%$ dry weight (Table 1). Beech nuts had the highest Importance Value during both autumn and early spring. They occurred at a high frequency and constituted a large proportion of total dry weight.

Table 1. Frequency percent (F\%), dry weight percent (W\%) and Importance Value as a percent (IV\%), of individual food items in the diet of brown bears in the Bieszczady Mountains. ${ }^{*}$ - trace amounts.

\begin{tabular}{|c|c|c|c|c|}
\hline Food item & Parts used & F\% & $\mathrm{W} \%$ & IV\% \\
\hline \multicolumn{5}{|c|}{ Autumn } \\
\hline Fagus silvatica & seeds & 39.0 & 23.3 & 36.9 \\
\hline Pirrus communis & fruits & 30.4 & 15.2 & 18.8 \\
\hline Avena sp. & grain & 17.4 & 16.1 & 11.4 \\
\hline Zea mays & fruits & 26.1 & 10.3 & 10.9 \\
\hline Cervidae & bones, hair & 21.7 & 6.5 & 5.7 \\
\hline Dicotyledonits & unidentified & 17.4 & 6.0 & 4.2 \\
\hline Triticum sp. & grain, stems & 13.0 & 6.5 & 3.4 \\
\hline Corylus avellana & fruits & 13.0 & 6.5 & 3.4 \\
\hline Pinaceae & wood, needles & 21.7 & 2.2 & 1.9 \\
\hline Beta vulgaris & roots & 8.7 & 3.5 & 1.2 \\
\hline Bos taurus & bones, hair & 13.0 & 1.3 & 0.7 \\
\hline Ovis aries & hair & 13.0 & 1.0 & 0.5 \\
\hline Graminae & leaves, seeds & 21.7 & $*$ & - \\
\hline Vespidae & imago & 17.4 & $*$ & - \\
\hline Vaccinium myrtillus & fruits & 13.0 & $*$ & - \\
\hline Insecta (other) & imago & 13.0 & $*$ & - \\
\hline unident. components & - & 8.7 & 0.7 & 0.2 \\
\hline \multicolumn{5}{|c|}{ Spring } \\
\hline Fagus silvatica & seeds & 69.6 & 56.6 & 78.5 \\
\hline Zea mays & fruits & 30.4 & 25.0 & 15.1 \\
\hline Cervidae & bones, hair & 26.1 & 5.8 & 3.0 \\
\hline Graminae & leaves, seeds & 13.0 & 7.2 & 1.9 \\
\hline Pinaceae & wood, needles & 13.0 & 1.2 & 0.3 \\
\hline Avena sp. & grain & 13.0 & 0.6 & 0.2 \\
\hline Rosa canina & fruits & 4.3 & 0.9 & 0.1 \\
\hline Ovis aries & hair & 4.3 & $*$ & - \\
\hline Bos taurus & bones, hair & 4.3 & * & - \\
\hline Sorex sp. & hair & 4.3 & * & - \\
\hline Insecta & imago & 4.3 & * & - \\
\hline unident. components & - & 17.4 & 2.7 & 0.9 \\
\hline
\end{tabular}




\section{Discussion}

In spite of its wide application, faeces analysis is a highly biased method for estimating diet composition, since it is based on identification of undigested food only. Examination of stomach contents gives more reliable results. The comparison between stomach contents and faeces of bears done by Hatler (1972) showed that the proportion of the animal component in faeces is considerably smaller than in the stomach. Therefore, the real share of beechnuts and crops in the diet of bears in Bieszczady Mts is probably much lower, and share of mammals larger, than faeces analyses have shown.

Individual autumn faeces in our sample contained proportionally more food items than spring faeces. This may result from the greater variety of food available in autumn, as well as from the bears' more intensive foraging in the period preceding hibernation, compared to other seasons.

Beechnuts are a calorie-rich food $(6976 \mathrm{cal} / \mathrm{g}$ of dry weight for nuts without shells; Grodziński and Sawicka-Kapusta 1970), and seem to be a significant source of energy in the pre-hibernation period. During this time, a bear's energy consumption may reach $20,000 \mathrm{kcal}$ per day (Nelson et al. 1983).

In early spring, during the first two weeks after leaving the winter lair, a bear's daily consumption of food is typically lower, in the range of $4,000-5,000 \mathrm{kcal}$ (Nelson et al. 1983), hibernation metabolism is equivalent to ca. $50 \%$ of normal basal metabolism (Watts and Jonkel 1988). At this time, beechnuts, which can be found in patches around trees where snow has melted, are the only food available near winter lairs. Forest areas situated at lower elevations earlier offer more diverse food, but at that time they are frequented by people looking for shed antlers. Therefore, consumption of calorie-rich beechnuts, providing sufficient amounts of energy to sustain slow post-hibernation metabolism, may make possible for the bears to stay in higher situated places, inaccessible to man.

A high proportion of beechnuts in autumn and early spring diets was also found for other bear populations (Zunino and Herrero 1972, Berducou et al. 1983, Cicnjak et al. 1984, Ohdachi and Aoi 1984). A drop in beechnut production, which occurs every few years may negatively influence the build-up of fat reserves for hibernation (Cicnjak 1984) as well as the bears' nutritional status in the difficult post-hibernation period. According to local foresters, in the autumn of 1990 beechnut production was very high.

Hazelnuts have a higher calorie content $(7,894 \mathrm{cal} / \mathrm{g}$ of dry weight for hazelnuts without shells) than beechnuts (Grodziński and Sawicka-Kapusta 1970). Their small contribution to the autumn diet may have been due to the timing of our sample collection since hazelnuts are during that period intensively gathered by the local people.

Crops were a significant component of the autumn and spring diet. They are easily available to bears in Bieszczady Mts; maize, oats and beets are placed near baiting sites and at game-feeding stations as food for wild boars. A high percentage 
of anthropogenic food in the bear's diet in areas where it is easily available was also reported from Abruzzo National Park (Zunino and Herrero 1972).

Pears appeared to be an important component in the autumn diet (Table 1). Numerous abandoned orchards are an abundant source of these fruits in the Bieszczady Mts.

Animal components, both autumn and spring, comprised a small proportion of samples. Our field observations indicate that bears often feed on carcasses from under raised hides. According to Clark suggestion (Clark 1957), bears prefer carcasses to fresh meat, however other authors reported different observations. In Bieszczady Mts, cattle and sheep carcasses are typically used to attract game, although deer killed by wolves are also used. As a rule, farm animals are flayed, which results in a decrease of identifiable pieces in the samples. The location of daybeds (W. Frąckowiak and R. Gula, unpubl.) provides further evidence that bears frequently forage on carrion from domestic livestock; of 15 daybeds found, 12 were situated within $800 \mathrm{~m}$ of baiting sites which carcasses were placed.

Grass occurred only as trace amounts in autumn samples, whereas in spring grass comprised a considerable proportion of faeces dry weight. This difference probably resulted from higher nutrient content and digestibility of grass during spring compared to autumn (Mealey 1980, Cicnjak et al. 1984).

An insect component was often present in the samples, but in small amounts. Wasps were most often found in samples containing pears, which suggests that the bears could have eaten them by chance. However, the authors observed bears digging at decaying logs in search of insect larvae, which indicates that insects may be an another source of protein during early spring.

This preliminary study indicates a large contribution by anthropogenic food. Strict protection of bears by law probably allows them greater access to this kind of food, which is likely to have a positive effect on the build-up of energy reserves for hibernation. In the spring, after the slow metabolic rate of hibernation has switched to the higher rate of normal activity (Nelson et al. 1983), carcasses and grain from baiting sites may enable bears to replenish fat reserves after hibernation. Availability of large amounts of nutritious nuts produced by old beech stands in high mountain areas apparently allows bears to remain undisturbed by humans near their winter lairs during the first two weeks after hibernation. Easy access to food from baiting sites may also help reduce conflicts between bears and tourists and farmers, despite increasing bear numbers.

Acknowledgement: This study was supported by the grant KBN 0434/92.

\section{References}

Aoi T. 1985. Seasonal change in food habits of ezo brown bear (Ursus arctos yesoensis Lydekker) in northern Hokkaido. Res. Bull., Teshio Exp. For., Hokkaido Univ. 42: 721 - 732.

Berducou C., Faliu L. and Barrat J. 1983. The food habits of brown bear in the National Park of the Western Pyrenees (France) as revealed by faeces analysis. Acta Zool. Fennica. 174: 153 - 156. 
Buchalczyk T. 1980. The brown bear in Poland. [In: Bears - their Biology and Management. C. J. Martinka and K. L. McArthur, eds]. Bear. Biol. Conf. Ser. 3: 229 - 232.

Cicnjak L., Huber D., Roth H. U., Ruff R. L. and Vinovrski Z. 1984. Food habits of brown bears in Plitvice Lakes National Park, Yugoslavia. Int. Conf. Bear Res. and Manage. 7: 221 - 226.

Clark W. K. 1957. Seasonal food habits of the Kodiak bear. Trans. North Am. Wildl. Conf. 22: $145-151$.

Grodziński W. and Sawicka-Kapusta K. 1970. Energy values of tree-seeds eaten by small mammals. Oikos 21: $52-58$.

Gula R. 1991. [Numbers and age structure of brown bears in Bieszczady Mountains]. M. Sc. Thesis. Jagiellonian University, Department of Wildlife Research, Krak6́w, Poland: 1 - 26. [In Polish]

Hatler D. F. 1972. Food habits of black bear in interior Alaska. Can. Field-Nat. 86: $17-31$.

Jakubiec Z. and Buchalczyk T. 1987. The brown bear in Poland: its history and present numbers. Acta theriol. $32: 289-306$.

Jamrozy G. 1989. On the occurrence of brown bear in the Polish Carpatian Mountains. Acta theriol. 34: $652-655$.

Mealey S. P. 1980. The natural food habits of grizzly bears in Yellowstone National Park, $1973-74$. [Bears - their Biology and Management. C. J. Martinka and K. L. McArthur, eds]. Bear Biol. Conf. Ser. 3: $281-292$.

Michna E. and Paczos S. 1972. Zarys klimatu Bieszczad Zachodnich. Wrocław, Ossolineum: $1-72$.

Nelson R. A., Folk G. E., Pfeiffer E. W., Craighead J. J., Jonkel Ch. J. and Steiger D. L. 1983. Behavior, biochemistry, and hibernation in black, grizzly, and polar bears. Int. Conf. Bear Res. and Manage. 5: $284-290$.

Ohdachi S. and Aoi T. 1984. Food habits of brown bears in Hokkaido, Japan. Int. Conf. Bear Res. and Manage. 7: $215-220$.

Sumner J. and Craighead J. J. 1973. Grizzly bear habitat survey in the Scapegoat Wilderness, Montana. Montana Coop. Wildl. Res. Unit, Missoula: 1-49.

Watts P. D. and Jonkel C. 1988. Energetic cost of winter dormancy in grizzly bear. J. Wildl. Manage. 52: $654-656$.

Zunino F. and Herrero S. 1972. The status of the brown bear (Ursus arctos) in Abruzzo National Park, Italy, 1971. Biol. Conserv. 4: $263-272$.

Received 2 March 1992, accepted 15 October 1992. 